\section{Increasing Library Skills of Horticulture Students}

\author{
Steven E. Newman ${ }^{1}$ and \\ Susan H. Ellsbury ${ }^{2}$
}

Summary. A library skills workbook was developed for horticulture students to provide them with instruction in the use of bibliographic research materials and services available to them from the university library system. The effectiveness of the library skills workbook was tested by comparing pre- and post-test scores of undergraduate and graduate students. International and national graduate students were compared. Graduate students scored higher on the pre-test than did undergraduates. Students from the United States scored higher than Asian students, but not higher than Latin American students. Students' knowledge of the library collection and layout were improved $21.3 \%$; however, undergraduate students' knowledge increased $13 \%$ more than that of graduate students.

$\mathrm{E}$ ffective library skills are required for all college students. Horticulture majors must spend considerable time in the library researching topics for term papers and class

'Associate Professor.. Department of Horticulture, Mississippi State University, P.O. Drawer T, Mississippi State, MS 39762-5519

${ }^{2}$ Associate Professor and Reference Librarian. Mitchell Memorial Library, Mississippi State University, P.O. Box 5408, Mississippi State, MS 39762-5408

Mississippi Agricultural and Forestry Experiment Station Journal Series no. J-7615, projects assigned from a diverse array of courses. A horticulture student at any university is faced with the need to locate very specialized scientific literature, but often receives little instruction in acquisition of science-related materials. Many students never get past the card catalogues and computer terminals or they retrieve only a few journals, which often are assigned by an instructor and not located independently by the student. Foreign students, not familiar with U.S. libraries, also spend many hours just learning the basic structure of the Library of Congress Classification System. Advanced library skills are even more important to graduate students. Many hours of laboratory or greenhouse work are wasted duplicating published research, which a few hours of library inquiry could eliminate.

Library resource guide material specifically designed for horticulture students is not available. Library skills of horticulture students at Mississippi State Univ. were first determined to be deficient during interviews with groups of students by members of a Cooperative State Research Service (CSRS) review committee during a regular 5 year review. Undergraduate students stated that they never used the library and were not required to do so. Graduate students further stated that the library at Mississippi State Univ. was difficult to use. Thus, a workbook was designed to ameliorate this problem.

"Science Resources: A Self-Paced Instructional Workbook" (Ellsbury et al., 1981), a library skills workbook originally developed for students in the biological sciences at Mississippi State Univ., was modified and expanded for use by horticulture and plant science students. "Science Resources: A Guide for Horticulture Students" (Ellsbury and Newman, 1989) was developed to provide horticulture students with instruction in the use of bibliographic research materials and services available to them from the Mississippi State Univ. library system. The horticulture library workbook consists of an introduction and 15 descriptive chapters, each followed by corresponding assignment sheets (Table 1). Five variations of assignments were developed for each question to minimize student collaboration. The first nine chapters familiarize students with location of li- 
Table 1. Table of contents for science resources: A gutide for borticulture students.

\section{Chapters \\ I. Introduction \\ II. Locating Libraries and Materials \\ 1. Library tour \\ 2. Search Strategy \\ 3. Public Card Catalog \\ 4. Library of Congress Subject Headings \\ 5. Classification Systems \\ 6. Locating Books \\ 7. Periodical Printout-Holdings \\ 8. Periodical Printout-Locations \\ 9. Serials Printout \\ III. Indices and Abstracts to Journal Literature \\ $\mathrm{BAI}=$ Biological and Agricultural Index \\ HOR = Horticultural Abstracts \\ $\mathrm{BA}=$ Biological Abstracts \\ BAG = Bibliography of Agriculture \\ $\mathrm{SCI}=$ Science Citation Index \\ $\mathrm{C}=\mathrm{CAIRS}$ \\ IV. Conclusion}

$V$. Subject Guide to Indices and Abstracts in the Sciences

brary facilities and provide specific instructions needed for access to library holdings. The concluding six chapters pertain to specific indices and abstracts to scientific journal literature.

The workbook includes a short descriptive text followed by self-paced sequential exercises that students complete as assignments outside the classroom or laboratory. Once each exercise is completed, the student progresses to a more advanced exercise requiring the newly learned skills. The materials are flexible in content, with chapters covering basic and specialized reference materials and services.

The effectiveness of the library skills workbook was tested by asking horticulture and plant science majors, both graduate and undergraduate, to take a pre-test, complete the workbook, and take a post-test 1 week later (Table 2). The pre- and post-test were identical, but the students were not advised of this. Forty-five students participated in the evaluation, 17 undergraduate and 28 graduate students. Eight of the graduate students were from Southeast Asian countries, seven from Latin America, and 13 from the United States. All of the undergraduate students were from the United States.
Initially, all scores among nationalities were pooled for comparing graduate and undergraduate students (Table 3). Next, undergraduate and graduate student scores were pooled for comparing nationalities. Analysis of the unpooled data resulted in trends similar to the pooled data (data not shown).

Student response to the workbook was favorable. Workbook scores were high (94.1) and not different among any student group. Upon completion of the workbook, many discovered rooms and floors in the library housing reference material previously unknown to them. The students were allowed to complete the exercises at their leisure and the time for completion ranged from 2 to $5 \mathrm{~h}$.
Graduate students scored higher on the pre-test than the undergraduate students (Table 3). Graduate students would be expected to have better library skills, having- had more academic experience. Students from the United States scored higher than Asian students. Latin American students had intermediate scores. This also was expected, because the US. students are more familiar with the U.S. college library system. Post-test scores were not similar between graduate students and undergraduate students. However, U.S. students scored higher than both Asian and Latin American students on the posttest.

Analysis of the difference between the pre-test and the post-test scores

\section{Table 2. Example questions from the pre- and post-test.}

The MSU libraries consist of the main library and __ branch(es).
$\begin{array}{ll}\text { 1. one } & \text { 3. eight } \\ \text { 2. three } & \text { 4. two }\end{array}$

In Mitchell Memorial Library, the card catalogs are located
1. to the right of the Reserve Desk.
2. near the elevator in the lobby.
3. directly across from the Circulation Desk.
4. to the right of the Information Desk.

The card catalog contains the entries for all books and serials in the library.

1. author, subject, and publisher

2. subject, title, and publication date

3. author, title, and subject

4. title, subject, and page number

The best way to determine what subject heading to look for in the card catalog is to 1. go directly to the subject card catalog.

2. look in the Library of Congress Subject Headings.

3. look at date card and find the "tracings".

4. search through a textbook for the subject.

To find the most recent issue of a major biological journal, you would look

1 . on the 5 th stack tier.

2. in the Social Sciences Reading Room.

3. on the current periodicals stack tier.

4. in the Physical and Biological Sciences Reading Room.

You are looking for recent journal articles on the breeding of superior strains of southern peas. The best resource to use is

1. Biological Abstracts.

2. Biological and Agricultural Index.

3. Reader's Guide to Periodical Literature.

4. Chemical Abstracts.

You need a journal article, but the library does not have the year you need. You may request a copy of the journal article through

1. CAIRS (Computer Assisted Information Retrieval System)

2. The Interlibrary Loan Service.

3. Physical and Biological Sciences Room.

4. Special Collections. 
Table 3. Results of pre- and post-test and the difference between the post- and pre-test scores for borticulture graduate and undergraduate students of Asian, Latin American, and U.S. nationalities.

\begin{tabular}{lccc}
\hline Students & $\begin{array}{c}\text { Pre- } \\
\text { test }(\%)\end{array}$ & $\begin{array}{c}\text { Post- } \\
\text { test }(\%)\end{array}$ & $\begin{array}{c}\text { Differ- } \\
\text { ence }(\%)^{2}\end{array}$ \\
\hline $\begin{array}{l}\text { Classification } \\
\text { Graduate }\end{array}$ & 62.5 & 79.7 & 17.2 \\
Undergraduate & 52.5 & 76.8 & 24.3 \\
Nationality & & & \\
Asian & 49.8 & 72.1 & 23.0 \\
Latin American & 57.2 & 76.5 & 19.8 \\
United States & 65.5 & 86.1 & 21.0 \\
\hline
\end{tabular}

'Difference as the difference between post-test and pre-test scores.

allowed a measure of improvement in an individual's library skills. The aver- age difference between pre- and posttests for all participants was $21.3 \%$. There were no differences between Asian, Latin American, or U.S. students in increased library skills (Table 3). However, undergraduate student skills increased $7.1 \%$ more than the graduate student skills.

"Science Resources: A Guide for Horticulture Students" was designed to ameliorate the deficiency in library skills among horticulture majors and appears to be successful. It is used now as a regular part of instruction in horticulture courses at Mississippi State Univ. International students in horticulture, new to the United States and Mississippi, are assigned the workbook as a regular part of their orientation.
Student corrections, evaluations, and ideas are being incorporated continually into new editions, along with information on the new computer facilities that have been installed in the library. The workbook is readily adaptable to other university libraries and copies are available upon request from us.

\section{Literature Cited}

Ellsbury, S.H., D. Wise, and M.M. Ellsbury. 1981. Science resources: A self-paced instructional workbook. Mississippi State Univ., Mississippi State.

Ellsbury, S.H. and S.E. Newman. 1989. Science resources: A guide for horticulture students. Mississippi State Univ., Mississippi State. 